\title{
The effects of the global economic crisis in Latin America
}

ARTURO GUILLÉN R.*

The aim of this article is to analyze the current phase of the global crisis and the way it has manifested itself in Latin America. The global crisis is the most important capitalist crisis since World War II. It is a new type of debt-deflation crisis, highlighting the limits of the finance-dominated regime of accumulation and characterized by securitization. Latin American countries have not been immune to the global crisis. Since it sets limits on globalization, the impossibility of maintaining exportdriven accumulation sustained by restrictive monetary and fiscal policies becomes clear. This time, there will be no way out in external markets for any country. That fact will force them to restructure productive systems and search for a way out in domestic markets and in regional spaces for integration.

Keywords: global crisis; latin america; deflation; recession; financialization.

JEL Classification: E32.

\section{INTRODUCTION}

The aim of this article is to analyze the current phase of the global crisis that began in the United States in 2007 and the way it has manifested itself in Latin America. The current phase, which began during the last quarter of 2008, is characterized by the interaction of the financial crisis - far from having been overcome - and the deepening and universal expansion of recession. The second section summarizes my position about the nature of the global crisis. The third section presents a proposal about the stages this crisis has already gone through. Fourth

\footnotetext{
*Full professor and researcher at the Economic Department of the Universidad Autónoma Metropolitana, Iztapalapa campus, Mexico City. Head, at the same university, of the Post graduate Program in Social Studies, Social Economics Area. E-mail: artguillenrom@hotmail.com. Paper presented at the Conference of the Association for Evolutionary Economics (AFEE), Atlanta, Georgia, January 2-5, 2010. Submitted: December 2009; Accepted: January 2010.
} 
section examines the main features of the present stage of the crisis: the advance of recession in the world economy and the development of deflation. The fifth section looks at the effects of the crisis in Latin America, and, finally, the sixth section presents some conclusions and perspectives.

\section{ABOUT THE CHARACTERIZATION OF THE GLOBAL CRISIS}

As I put forward in a previous article (Guillén, 2009), the global crisis is the most important capitalist crisis since World War II. It is a new type of debt-deflation crisis, highlighting the limits of the finance-dominated regime of accumulation in place since the 1980s and characterized, among other things, by securitization, that is, a financing regime based on issuing securities and derivatives.

Setting up this finance-dominated accumulation regime sustained by liberalization, deregulation, and the globalization of goods and financial markets was the response of the cutting-edge sectors of capital and the main capitalist powers when confronted with the "great crisis" that began in the late 1970s. That great crisis put an end to the state-monopoly mode of regulation in place since World War II and the Fordist regime of accumulation it was based on (De Bernis, 1988). It is my opinion that today's global crisis is not a new "great crisis", but rather an extension of the one from the 1970s.

Neoliberal globalization fostered a new regime of accumulation dominated by finance, but was incapable of establishing a new mode of regulation. While this regime of accumulation made it possible for some capital sectors to amass enormous fortunes, it was incapable of ensuring the structural stability for capital reproduction in the system as a whole.

Globalization, deregulation, and financial liberalization deepened financial markets' fragility, encouraging over-indebtedness by economic agents. These trends were actually processes that restructured productive systems to deal with the "great crisis" of the 1970s, to find new ways of reproducing capital and changing the relations between capital and labor to favor the former (Guillén, 2007, p. 287).

In addition, as several analysts have pointed out (Borón, 2009; Guillén 2009; Chesnais 2009), this crisis is unprecedented and multifaceted. The economic and financial crisis combines with others: the food crisis, the ecological crisis, and the global warming crisis; and with the limits of an energy paradigm and a mode of consumption based on the use and abuse of fossil fuels. In many ways, we are facing what Braudel called the crisis of "Western civilization".

\section{THE STAGES OF THE GLOBAL CRISIS}

As mentioned above, the global crisis is a prolongation of the "great crisis" of the 1970s, which was not resolved with neoliberal globalization. Quite to the con- 
trary, the latter aggravated financial instability and deflationary tendencies. Several years ago, G. de Bernis (1986) proposed the hypothesis that all great crises, regardless of their specific differences, go through two major phases: a first one in which inflationary trends and international expansion predominate; and a second one in which deflationary trends and closing off of economies hold sway. Based on this hypothesis, I posited (Guillén, 1991) that in the case of the "great crisis" of the 1970s - which we still have not left behind us - the first clearly inflationary stage concluded in 1982 with the foreign debt crisis. This led to financial globalization and to the second phase, marked by a series of systemic debt-deflation financial crises: Japan (1990), Mexico (1994-1995), East-Asia (1997-1998), the 2000 NASDAQ crisis, Argentina (2001), and culminating in the current global crisis with its epicenter in the United States.

The current global crisis already has a history of its own. Up until now, it has gone through two stages. The first stretched from August 2007 to September 2008. This is when the subprime mortgage crisis broke out, with its gradual but inexorable collapse of the bond and mortgage-based derivatives market (CDSs, investment vehicles etc.). Since the entire financial pyramid was built on a foundation of indebtedness, in this stage, credit began to contract. The impact on stock markets was limited: in the central countries, they dipped slightly, but in many emerging countries they continued to rise. The stock market fall began in July and August 2008 when turbulence on the bonds market stepped up (see Table 1, p. 190). During that stage, the impact on the real economy was limited. Some analysts even doubted that the financial crisis could lead to a recession, much less a recession generalized throughout the world economy.

The second stage has lasted roughly from September 2008 until today and is characterized by a sharp contraction of credit in all markets; the beginnings of the banking crisis; the bankruptcy and virtual disappearance of investment banks and its absorption by the commercial banks; deepening deflationary trends in central economies; plummeting stock markets; and the beginning of a generalized recession.

During the first stage, the turbulence emerged from the financial sector and passed over into the real economy. In the second stage, the movement is both ways: from finance to the real economy and from the real economy to the financial sector. As the IMF recognizes, there is "negative feedback" between deteriorated financial sectors and weak economies (IMF, 2009a, pp. xii-xiii).

Symptoms of recovery began to show up in March 2009 in some economies (an upturn in GDP and stock markets, renewed risky financial operations, price hikes of some primary products, etc.). According to some analysts, this might indicate that the crisis is coming to a close. Is it really the end of the crisis or is this a new bubble that will sooner or later make existing problems even worse? It's too soon to know. In any case, the only thing that is certain is that uncertainty about the future of the economy and the end of the crisis will continue. 


\begin{tabular}{|c|c|c|c|c|c|c|c|c|c|c|c|c|c|c|c|c|c|c|c|}
\hline 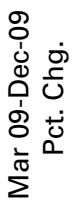 & $\begin{array}{l}\text { ○ } \\
\text { ஸे }\end{array}$ & $\begin{array}{l}\stackrel{L}{+} \\
\stackrel{\infty}{+} \\
\stackrel{+}{+}\end{array}$ & $\begin{array}{l}\stackrel{\circ}{\rho} \\
\stackrel{\rho}{m}\end{array}$ & $\begin{array}{l}\stackrel{\llcorner}{\infty} \\
\infty \\
\stackrel{\varphi}{q}\end{array}$ & $\begin{array}{l}\text { N } \\
\stackrel{+}{+}\end{array}$ & $\frac{\bar{n}}{\bar{n}}$ & $\begin{array}{l}\text { 우 } \\
\text { مे }\end{array}$ & $\begin{array}{l}\text { O } \\
\circ \\
\text { ஸे }\end{array}$ & $\begin{array}{l}\underset{N}{N} \\
\infty \\
\infty\end{array}$ & 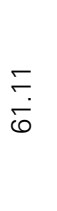 & $\begin{array}{l}\infty \\
\infty \\
\infty \\
\infty\end{array}$ & $\begin{array}{l}\infty \\
\infty \\
\dot{\gamma}\end{array}$ & $\begin{array}{c}\infty \\
\text { m }\end{array}$ & $\begin{array}{l}\stackrel{0}{\circ} \\
\text { ○ें } \\
\text { ले }\end{array}$ & $\begin{array}{l}\check{\epsilon} \\
\dot{\theta}\end{array}$ & $\begin{array}{l}\stackrel{P}{1} \\
\dot{j}\end{array}$ & $\begin{array}{c}\text { مٌ } \\
\stackrel{0}{0}\end{array}$ & 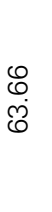 & 仓ે \\
\hline 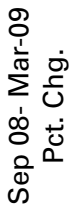 & $\begin{array}{l}\infty \\
\infty \\
\stackrel{\sim}{\sim} \\
\underset{\uparrow}{*}\end{array}$ & $\begin{array}{l}\text { O } \\
\stackrel{0}{ } \\
\stackrel{1}{1}\end{array}$ & $\frac{\circ}{\stackrel{\circ}{க}}$ & 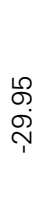 & $\begin{array}{l}\infty \\
\text { m } \\
\stackrel{0}{p} \\
\text { p. }\end{array}$ & $\begin{array}{l}\oplus \\
\stackrel{0}{0} \\
\ddot{1}\end{array}$ & 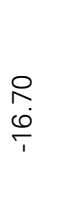 & $\begin{array}{l}\stackrel{0}{0} \\
\stackrel{\leftrightarrow}{m}\end{array}$ & 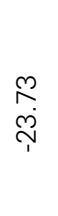 & 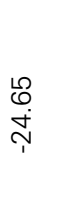 & \begin{tabular}{l}
$\bar{\Gamma}$ \\
$\dot{\sim}$ \\
\multirow{T}{*}{}
\end{tabular} & $\begin{array}{l}\stackrel{\sim}{m} \\
\underset{+}{+}\end{array}$ & $\begin{array}{l}\text { న్ } \\
\stackrel{+}{\sigma}\end{array}$ & 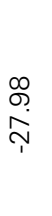 & $\begin{array}{l}\stackrel{\llcorner}{\llcorner} \\
\stackrel{\sim}{\top} \\
\stackrel{1}{\top}\end{array}$ & $\begin{array}{l}\circ \\
\infty \\
\stackrel{1}{N} \\
\stackrel{1}{1}\end{array}$ & 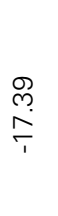 & $\underset{⿱ 亠}{\stackrel{\nabla}{\leftarrow}}$ & $\begin{array}{l}\text { బิ } \\
\text { o }\end{array}$ \\
\hline $\begin{array}{ll} & 0 \\
0 & 0 \\
0 & 0 \\
1 & 0 \\
0 & 0 \\
0 & 0 \\
5 & 0 \\
5 & 0\end{array}$ & $\begin{array}{l}\infty \\
\circ \\
\stackrel{0}{\circ} \\
\end{array}$ & $\begin{array}{l}\stackrel{\sigma}{0} \\
\stackrel{\sigma}{\top}\end{array}$ & $\begin{array}{l}\underset{i}{N} \\
\underset{N}{N}\end{array}$ & $\underset{\sim}{\stackrel{\infty}{\tau}}$ & 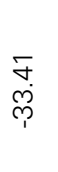 & 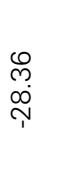 & $\begin{array}{l}\stackrel{2}{\Omega} \\
\oplus \\
\stackrel{1}{1}\end{array}$ & 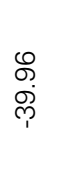 & $\begin{array}{l}\bar{\varphi} \\
\dot{\varphi} \\
\stackrel{\gamma}{\gamma}\end{array}$ & $\begin{array}{l}\stackrel{\llcorner}{N} \\
\underset{1}{T}\end{array}$ & $\begin{array}{l}\underset{1}{\sim} \\
\underset{1}{T}\end{array}$ & $\begin{array}{l}\stackrel{\odot}{\sim} \\
\underset{+}{\sim}\end{array}$ & 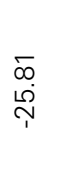 & 命 & 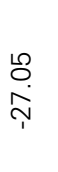 & $\begin{array}{l}\stackrel{0}{N} \\
\stackrel{\omega}{\circ} \\
\frac{1}{1}\end{array}$ & $\begin{array}{l}\text { ूे } \\
\text { क् }\end{array}$ & $\begin{array}{l}\stackrel{ }{\circ} \\
\stackrel{i}{i}\end{array}$ & 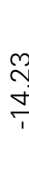 \\
\hline 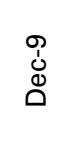 & 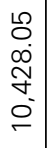 & 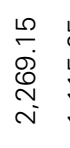 & 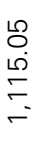 & 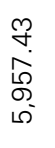 & $\begin{array}{l}m \\
m \\
0 \\
m \\
m \\
m^{-}\end{array}$ & $\begin{array}{l}\stackrel{N}{\sim} \\
\stackrel{\sim}{\sim} \\
\stackrel{-}{-}\end{array}$ & 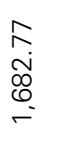 & $\begin{array}{l}\stackrel{+}{\leftarrow} \\
\stackrel{N}{N} \\
\stackrel{n}{n}\end{array}$ & 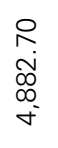 & $\begin{array}{l}\stackrel{0}{\llcorner} \\
\stackrel{N}{N} \\
\infty \\
\stackrel{\infty}{N}\end{array}$ & 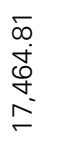 & $\begin{array}{l}\infty \\
\stackrel{\infty}{N} \\
\stackrel{N}{-}\end{array}$ & 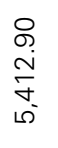 & 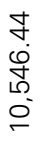 & $\begin{array}{l}\text { N } \\
\stackrel{\circ}{N} \\
\text { m} \\
\sim\end{array}$ & 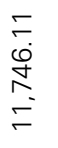 & $\begin{array}{l}8 \\
\infty \\
\infty \\
\infty \\
\llcorner \\
\infty 0^{-} \\
0\end{array}$ & 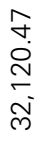 & 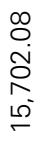 \\
\hline $\begin{array}{l}8 \\
\frac{1}{10} \\
\frac{1}{\pi} \\
\sum\end{array}$ & $\begin{array}{l}N \\
\infty \\
\infty \\
\varnothing \\
\stackrel{N}{ }\end{array}$ & 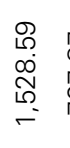 & 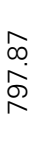 & $\begin{array}{l}\stackrel{0}{N} \\
\stackrel{+}{0} \\
\infty \\
0 \\
\dot{\sigma}\end{array}$ & $\begin{array}{l}\text { ले } \\
\text { Oे } \\
\infty \\
\sim \\
N\end{array}$ & $\begin{array}{l}\hat{0} \\
\stackrel{0}{0} \\
\infty\end{array}$ & 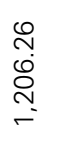 & $\begin{array}{l}\bar{N} \\
\stackrel{N}{N} \\
\stackrel{n}{N}\end{array}$ & 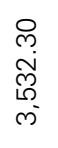 & 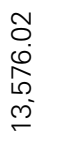 & $\begin{array}{l}\circ \\
\circ \\
\infty \\
\circ \\
\circ \\
\sigma^{\circ}\end{array}$ & $\begin{array}{l}\stackrel{\llcorner}{\llcorner} \\
\stackrel{\infty}{\infty} \\
\stackrel{\infty}{i}\end{array}$ & \begin{tabular}{l} 
을 \\
$\dot{0}$ \\
\multirow{N}{}{} \\
$\dot{m}$
\end{tabular} & $\begin{array}{l}\text { M } \\
\stackrel{1}{0} \\
0 \\
\overline{0} \\
\infty\end{array}$ & 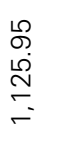 & 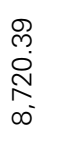 & $\begin{array}{l}8 \\
0 \\
\dot{0} \\
\tilde{\sigma} \\
\stackrel{+}{\circ}\end{array}$ & 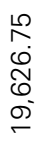 & 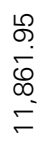 \\
\hline $\begin{array}{l}\infty \\
0 \\
i \\
\stackrel{1}{0} \\
\stackrel{\infty}{\infty}\end{array}$ & 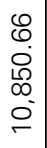 & $\begin{array}{l}\infty \\
\infty \\
\infty \\
\\
\\
i\end{array}$ & 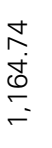 & 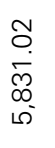 & 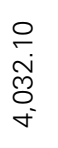 & 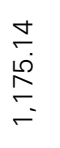 & $\begin{array}{l}\mathscr{Q} \\
\stackrel{0}{0} \\
\stackrel{+}{+} \\
\stackrel{-}{-}\end{array}$ & $\begin{array}{l}\infty \\
N \\
\stackrel{\infty}{N} \\
\stackrel{N}{v}\end{array}$ & 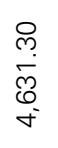 & $\begin{array}{l}\bar{ָ} \\
6 \\
0 \\
\infty \\
\infty\end{array}$ & $\begin{array}{l}\text { M } \\
\dot{8} \\
\& \\
\infty \\
\stackrel{\sim}{\sim}\end{array}$ & $\begin{array}{l}\infty \\
0 \\
\infty \\
\infty \\
\vdots \\
-\end{array}$ & 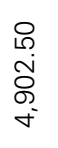 & 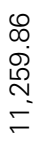 & 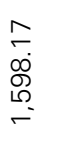 & $\begin{array}{l}\text { ᄋ } \\
\text { กิ } \\
\text { م⿱ } \\
\text { Е } \\
=\end{array}$ & $\begin{array}{l}8 \\
\circ \\
\dot{+} \\
\text { டீ } \\
\text { gं }\end{array}$ & 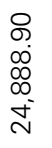 & 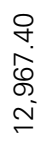 \\
\hline $\begin{array}{l}\text { O } \\
\stackrel{1}{1} \\
5 \\
3\end{array}$ & 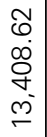 & 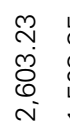 & 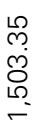 & 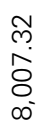 & $\begin{array}{l}M \\
\sigma \\
\dot{+} \\
\stackrel{0}{0} \\
0\end{array}$ & 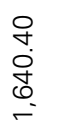 & 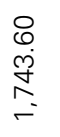 & 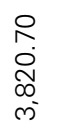 & $\begin{array}{l}8 \\
\dot{0} \\
\stackrel{0}{m} \\
\sigma^{-}\end{array}$ & $\begin{array}{l}\stackrel{M}{N} \\
\stackrel{N}{N} \\
\stackrel{N}{N}\end{array}$ & 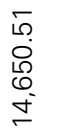 & 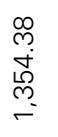 & $\begin{array}{l}8 \\
\text {. } \\
8 \\
৫ \\
0\end{array}$ & $\begin{array}{l}\infty \\
m \\
\infty \\
m \\
\\
\stackrel{\infty}{\sigma}\end{array}$ & $\begin{array}{l}\hat{\infty} \\
\circ \\
\infty \\
\stackrel{\circ}{\sim}\end{array}$ & 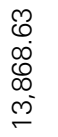 & 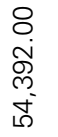 & $\begin{array}{l}\stackrel{L}{0} \\
\frac{5}{\infty} \\
\frac{5}{m}\end{array}$ & $\begin{array}{l}\stackrel{\llcorner}{\infty} \\
\infty \\
\stackrel{0}{\sigma} \\
\stackrel{\circ}{\sigma}\end{array}$ \\
\hline 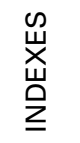 & $\overline{\bar{D}}$ & 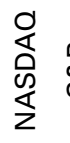 & $\stackrel{0}{\not}$ & $\begin{array}{l}\bar{x} \\
\text { 㐫 }\end{array}$ & 폰 & $\sum_{\omega}^{\bar{\infty}}$ & $\underset{\bar{\sigma}}{\bar{\sigma}}$ & $\begin{array}{c}\text { 山 } \\
\text { 心 }\end{array}$ & $\begin{array}{l}\stackrel{0}{0} \\
\stackrel{0}{0} \\
\stackrel{<}{<}\end{array}$ & 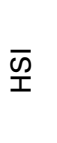 & $\begin{array}{l}\text { Z } \\
\text { w } \\
\text { ص }\end{array}$ & 岕 & $\begin{array}{l}山 \\
\stackrel{\omega}{4}\end{array}$ & $\stackrel{\stackrel{N}{N}}{z}$ & $\underset{\mathbf{N}}{\stackrel{\mathscr{N}}{Z}}$ & $\frac{\omega}{\omega}$ & 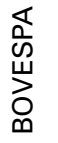 & U & 秀 \\
\hline 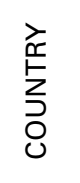 & $\begin{array}{l}\overleftarrow{心} \\
\stackrel{\jmath}{\supset}\end{array}$ & 岕 & 芯 & 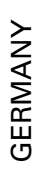 & 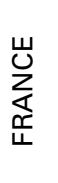 & $\frac{z}{\frac{1}{\Delta}}$ & 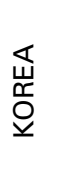 & 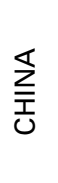 & 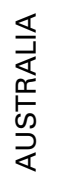 & 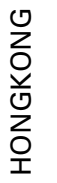 & $\begin{array}{l}\overleftarrow{\Delta} \\
\grave{2}\end{array}$ & 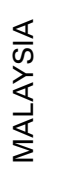 & 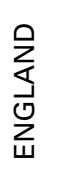 & $\begin{array}{l}z \\
\frac{1}{\alpha} \\
\frac{1}{3}\end{array}$ & 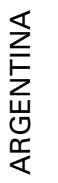 & 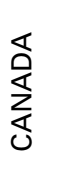 & $\begin{array}{l}= \\
\frac{\infty}{\infty} \\
\frac{1}{\infty}\end{array}$ & $\begin{array}{l}\stackrel{\bigcirc}{\mathcal{U}} \\
\frac{X}{x} \\
\stackrel{u}{\Sigma}\end{array}$ & 岂 \\
\hline
\end{tabular}




\section{MAIN FEATURES OF THE PRESENT STAGE OF GLOBAL CRISIS}

Two features stand out in the current phase of the crisis that began in September 2008:

- The depth and almost universal spread of the recession.

- The advance of deflationary tendencies.

Elsewhere (Guillén, 2010a), I have dealt in greater detail with these processes. Here, I will just underline their most important features.

\section{The worldwide recession}

economic activity was paralyzed in practically the entire world with unprecedented synchronicity. According to the Bureau of Economic Analysis (BEA), the U.S. recession began in December 2007. If it actually did end during the third quarter of 2009, this means that it lasted 17 months, making it the longest depressive cycle since World War II, including the 1974-1975 and 1980-1982 recessions. GDP dropped for four consecutive quarters, including the biggest declines since the Great Depression of the 1930s: $-6.3 \%$ and $-6.4 \%$, respectively, for the fourth quarter of last year and the first quarter of this year. There was a worrying slowdown in private consumption, which has been the driving force behind the U.S. economy in recent years. For its part, investment in all its forms has dried up (commercial buildings, equipment, and housing). Since the recession began, gross fixed investment contracted during six quarters.

When the financial crisis hit hard the last quarter of 2007, in some circles there was the erroneous belief, the myth, that certain countries could "decouple" themselves from its effects. The idea gained popularity that even in the case of a recession in the United States, the world economy's growth cycle would be maintained in the European Union, Asia, and the emerging countries (see Soros, 2008). It soon became clear that this "decoupling" did not exist, much less in an economy as globalized as today's. In a previous publication (Guillén, 2009), I maintained that the crisis would globalize for two reasons: first, because the real estate "bubble" was not a U.S. phenomenon, but involved many countries; and second, because the orgy of securitization and derivatives also involved European and Asian banks and financial intermediaries. It is also difficult to imagine decoupling in a world that is more integrated than ever through foreign trade and financial flows. Neither is it possible to expect decoupling in the framework of a world financial "architecture" in which the United States acts as the buyer of last resort by financing its deficits through external savings.

Some economies like China or India may be able to resist the onslaught of the crisis and keep growing but most of countries have gone into recession. The recession is generalized and deep. It involved the United States, the European Union and a large number of countries on the periphery. In Tables 2 and 3, I have 
gathered quarterly growth data for 32 of the world's most important economies. If we use the conventional definition of a recession (two consecutive quarters of negative GDP growth), we can see that in the first quarter of 2009, at least 21 countries were in recession, including most of developed nations and some of the more important emerging nations. The IMF recognizes that in 2009 per capita output will decrease in countries that represent three-fourths of world output (IMF, 2009, p. xi).

Table 2: Real GDP Growth in Developed Countries

\begin{tabular}{|c|c|c|c|c|c|c|c|c|c|c|}
\hline \multicolumn{9}{|c|}{ Quaterly change from a year ago } \\
\hline & 2006 & 2007 & 2008 & \multicolumn{3}{c|}{2008} & \multicolumn{3}{c|}{ Quarterly } \\
\hline COUNTRIES & & & & I & II & III & IV & I & II & III \\
\hline EURO AREA & 2.8 & 2.6 & 0.5 & 3.3 & -0.7 & -0.8 & -5.7 & -9.8 & -0.4 & 1.5 \\
\hline GERMANY & 2.9 & 2.2 & 1.0 & 6.5 & -0.4 & -2.1 & -8.2 & -14.4 & 1.3 & 2.9 \\
\hline FRANCE & 2.0 & 1.9 & 0.4 & 2.3 & -0.3 & 0.6 & -4.6 & -4.7 & 1.4 & 1.0 \\
\hline SPAIN & 3.9 & 3.8 & 0.9 & 1.7 & 0.1 & -2.0 & -3.8 & -7.4 & -4.2 & -1.2 \\
\hline ITALY & 1.8 & 1.5 & -1.0 & 2.1 & -1.1 & -2.0 & -7.1 & -9.4 & -1.9 & 2.3 \\
\hline NETHERLAND & 3.0 & 3.5 & 2.0 & 3.8 & 0.5 & 0.1 & -3.4 & -10.7 & -3.4 & 1.8 \\
\hline USA & 2.9 & 2.2 & 0.4 & -0.7 & 3.3 & -0.5 & -6.2 & -6.1 & -1.0 & 2.2 \\
\hline JAPAN & 2.4 & 2.1 & -1.2 & 5.6 & -3.0 & -0.4 & -12.7 & -15.2 & 3.7 & 1.3 \\
\hline UNITED KINGDOM & 2.9 & 3.1 & 0.6 & 2.9 & 0.8 & -2.0 & -6.0 & -7.4 & -3.2 & -1.2 \\
\hline CANADA & 2.8 & 2.7 & 0.4 & -0.7 & 0.3 & 1.3 & -3.4 & -5.4 & -3.4 & 0.4 \\
\hline SWEDEN & 3.3 & 4.1 & -0.5 & 1.8 & -0.1 & -0.4 & -9.3 & -3.6 & -0.1 & 0.7 \\
\hline SWITZERLAND & 3.2 & 3.1 & 1.8 & 2.3 & 1.5 & 0.1 & -1.2 & -16.0 & -1.0 & 1.2 \\
\hline
\end{tabular}

Source: Based on data of IMF, World Economic Outlook, 2008 and The Economist. 


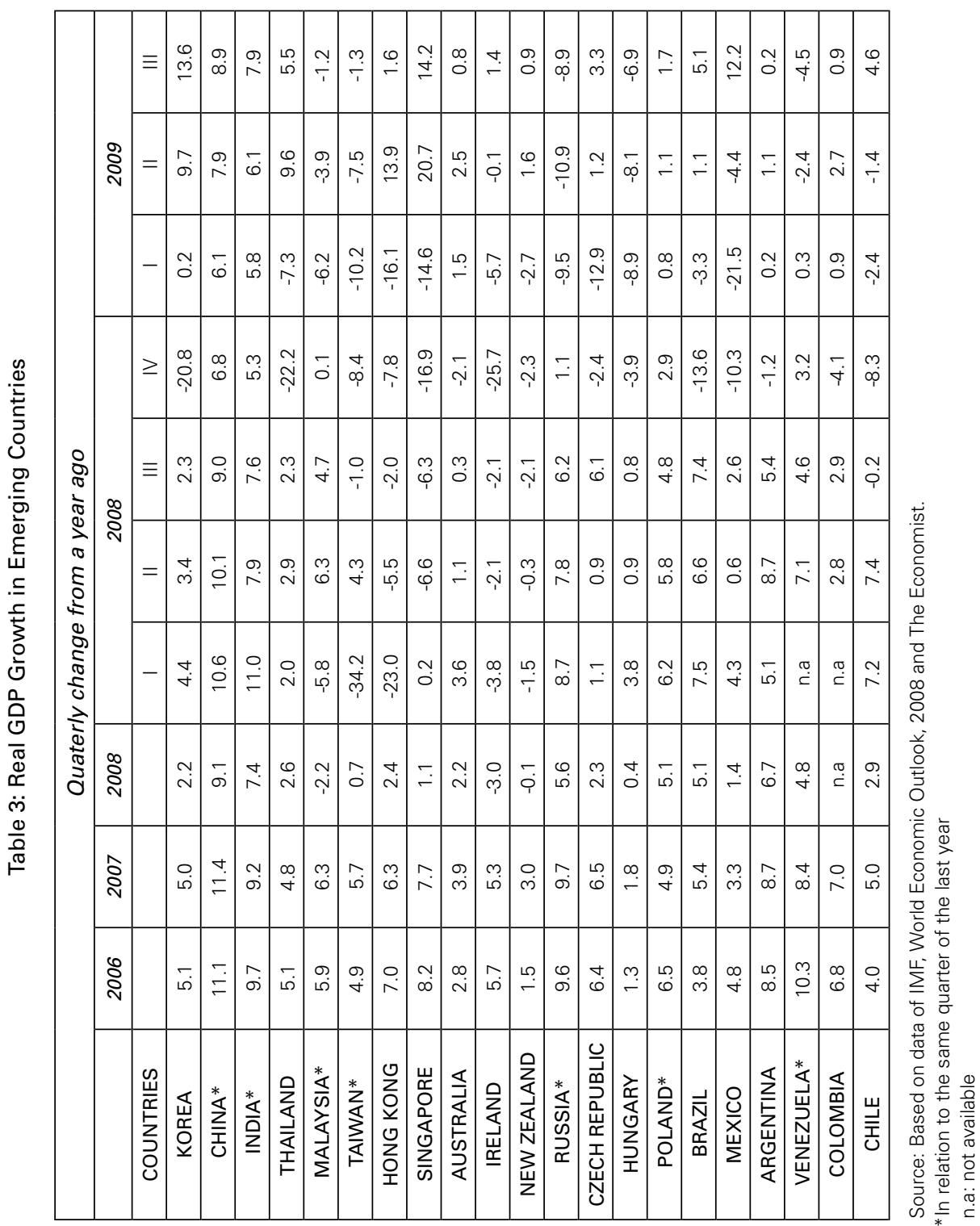




\section{Deflationary Tendencies}

All the great crises of capitalism lead to systemic financial crises. And all the great financial crises are debt-deflation crises. The current one is no exception.

Deflation is always linked to processes of over-indebtedness of economic agents. Total U.S. debt as a percentage of GDP has shot up since the 1990s dotcom bubble; since then it has not stopped growing. It increased from $151 \%$ of GDP in 1959 to $373 \%$ in 2007 (Foster, 2009). As a result of the "financialization" of the economy that began in the 1980s as a response to the 1970s crisis, financial sector debt soared from $22 \%$ of GDP to $117 \%$ in the fourth quarter of 2008 . In the United Kingdom gross financial sector debt reached 250\% of GDP (Wolf 2009).

Of course, as I have put forward elsewhere (Guillén, 2007), deflation does not manifest in the same way in contemporary capitalism as it did in the 1930s. Because of the very characteristics of the modes of regulation of those times, deflation was open and generalized. In contemporary capitalism, in contrast, what we have is a "contradictory deflation". The deflation of prices is checked by a series of mechanisms (lender of last resort, budget deficits etc.); this makes the deflationary process generally manifest itself over prolonged periods of economic stagnation and accompanied by the reproduction of fragile financial structures that are validated through government mechanisms to prevent a depression.

However, this does not mean that these mechanisms will always be effective and that open deflation cannot happen. Although the world is not yet facing generalized deflation, the dangers are real. Up until now, deflation has been sectoral and concentrated in the following markets:

- Real estate

- Stock markets and bonds markets

- Primary products

- Productive activities in structural crisis

The deflation in the U.S. real estate market that gave rise to the current financial crisis is not over yet. Although in the last months, the U.S. real estate market has stabilized relatively, sales continue to be extremely low. Many other countries are experiencing deflationary real estate prices. In March 2009, 16 countries registered dropping property values, compared to only six countries in the previous quarter (The Economist, 2009).

Another sector touched by deflation are primary product prices, whose drop affected the peripheral countries and revalidated the theory of the deterioration of the terms of exchange developed by Prebisch (1948) and Singer (1949) after World War II. The Economist commodities price index dropped $40 \%$ between August 2008 and March 2009.

To conclude, in the sectoral deflationary forces, we have industrial activities in structural crisis, like the auto industry, aviation or steel and iron or aluminum production, all of which have resorted to open or veiled price reductions.

Signs that the world economy's main countries may be entering into a process of generalized deflation continue to proliferate. Deflationary tendencies are not 
confined to the United States: they involve most of the countries in the European Union, Japan, China, and Taiwan. In March, almost 20 countries registered annual drops in wholesale prices, and almost a dozen registered monthly drops in consumer prices (see Figures 1 and 2).

Figure 1: Inflation (\%Monthy Variation) January 08 - October 09

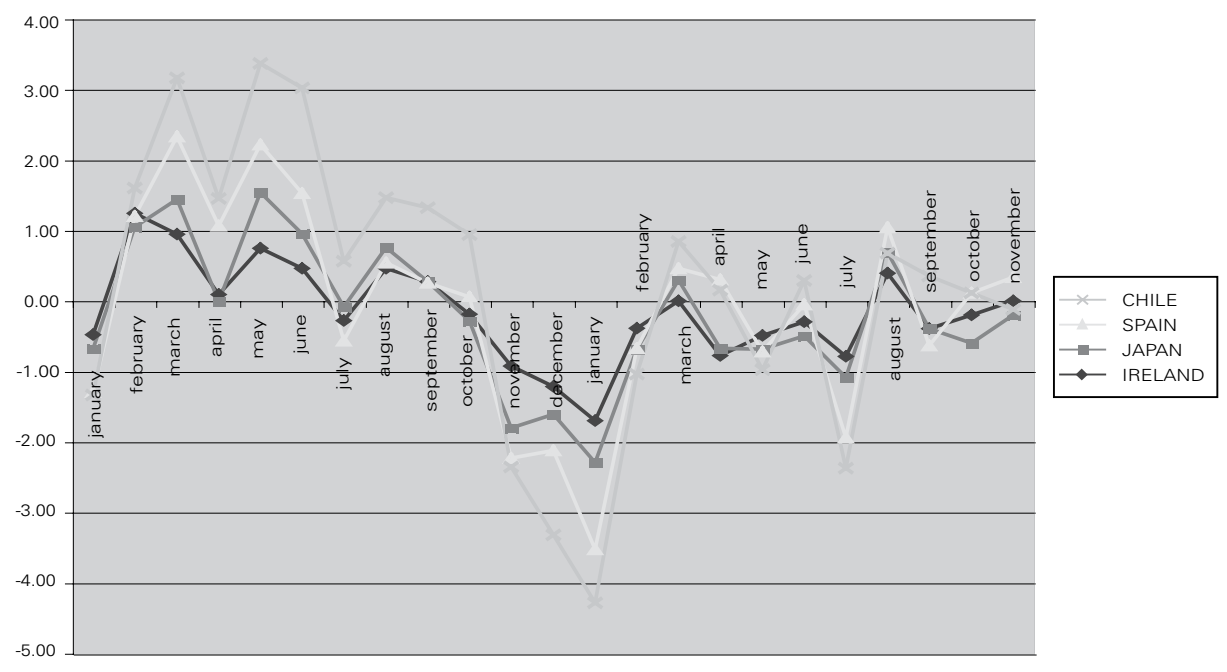

Source: OECD

Figure 1: Inflation (\% Monthy Variation) January 08 - October 09

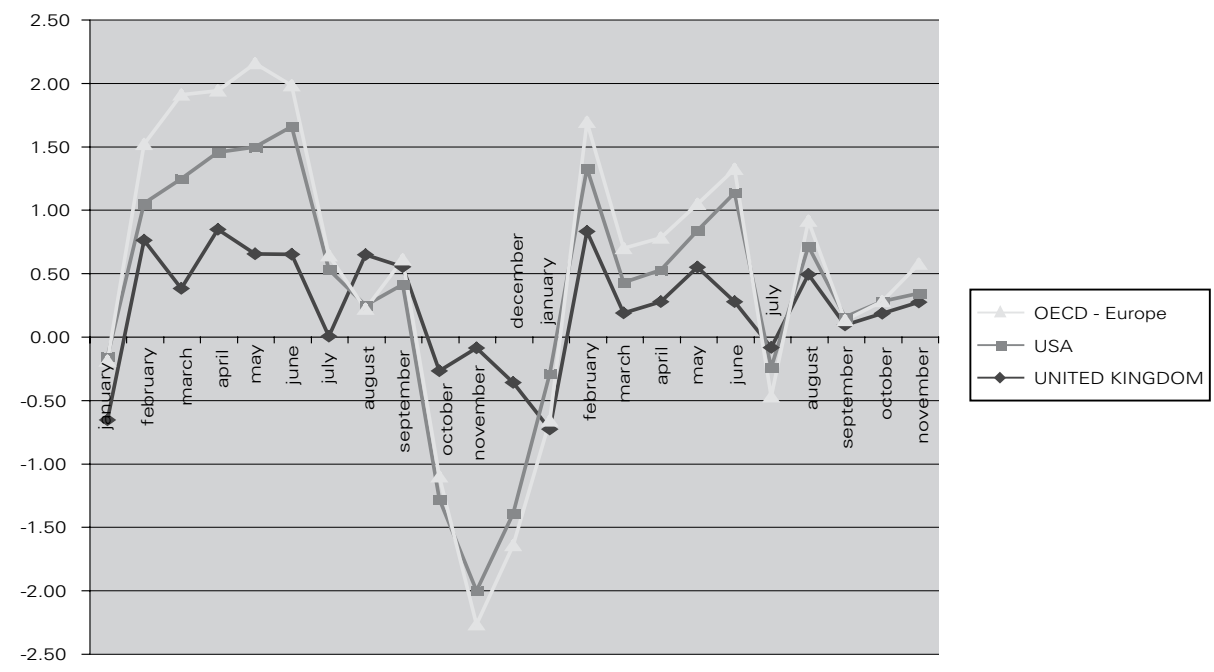

Source: OECD 
I am not suggesting here that the world will necessarily repeat the deflationary experience of the depression of the 1930s. Historical conditions are different. Governments and central banks have injected massive amounts of resources to contain deflationary tendencies. However, the results until now have been insufficient. The credit crunch continues and banks are reluctant to loan. Using monetary policy as a mechanism to stave off a depression has reached its limits. The financial and productive processes feed on each other: the deepening recession kindles the financial crisis, and the continuing financial crisis deepens the recession. If deflationary trends take hold, real interest rates will skyrocket, making it more difficult for economic agents to get out of debt and aggravating the credit crunch and the productive system's weakness.

\section{THE GLOBAL CRISIS IN LATIN AMERICAN COUNTRIES}

Latin American countries are not immune to the global crisis. It hit this region as it was emerging from one of the most intense periods of expansion in recent decades. According to ECLAC figures, regional GDP grew an annual average of $5 \%$ between 2003 and 2008. This is a median increase of more than $3 \%$ per capita, a figure that had not been achieved since the days of the import substitution model (ECLAC, 2008, p. 13). Some countries like Argentina and Venezuela did even better, with growth rates of more than $8 \%$ for several consecutive years.

Latin America's good economic performance in this period was due to a substantial improvement in the terms of exchange, growing exports, and high prices for primary products. But also, in the case of several countries, like precisely Argentina and Venezuela and others, it was due to their abandoning Washington Consensus directives, seeking out alternative strategies for development, and applying active monetary, fiscal, and wage policies.

The recession began in Latin America during the fourth quarter of 2008 (Figure 3 and Table 4). Last July, the ECLAC was predicting a $-1.9 \%$ contraction of GDP for 2009. The last IMF report (2009b) foresaw an even greater drop: $-2.5 \%$. The IMF also predicted that the GDP of 18 of the 32 countries in Latin America and the Caribbean would contract in 2009, including those of the largest countries: Brazil, Argentina, and Mexico.

The main mechanisms for transmitting the crisis have been the deterioration in the terms of trade, shrinking remittances from emigrants, and the massive withdrawal of private capital from financial markets.

The ECLAC estimates that the terms of trade in the region will fall $15 \%$ in 2009 (2008, p. 22). Prices of primary products have plummeted. In February 2009, they had dropped vis-à-vis their peak at the height of expansion as follows: oil, $51 \%$; food, $18 \%$; rice, $50.6 \%$; maize, $47.9 \%$; wheat, $41.9 \%$; metals, $49 \%$; and 
Table 4: Latin AMERICA GDP Growth

\begin{tabular}{|c|ccccc|}
\hline \multirow{2}{*}{ COUNTRIES } & & & & & 2009 \\
\cline { 4 - 6 } & 2007 & 2008 & Q-I & Q-II & Q-III \\
\hline Latin America & 4.5 & 2.7 & -18.4 & 1.6 & 9.3 \\
Argentina & 8.7 & 6.7 & 0.2 & 1.1 & 0.2 \\
Brazil & 5.4 & 5.1 & -3.5 & 4.4 & 5.1 \\
Mexico & 3.3 & 1.3 & -21.5 & -4.4 & 12.2 \\
Colombia & 7.5 & 2.6 & 0.3 & 2.7 & 0.9 \\
Uruguay & 7.6 & 8.9 & -2.3 & 1.2 & 2.5 \\
Venezuela & 8.2 & 4.8 & -52.3 & 27.1 & 0.9 \\
\hline
\end{tabular}

Source: CEPAL-CEPALSTAT, The Economist and http://www.cesla.com

Figure 3: Growth of GDP in Latin America

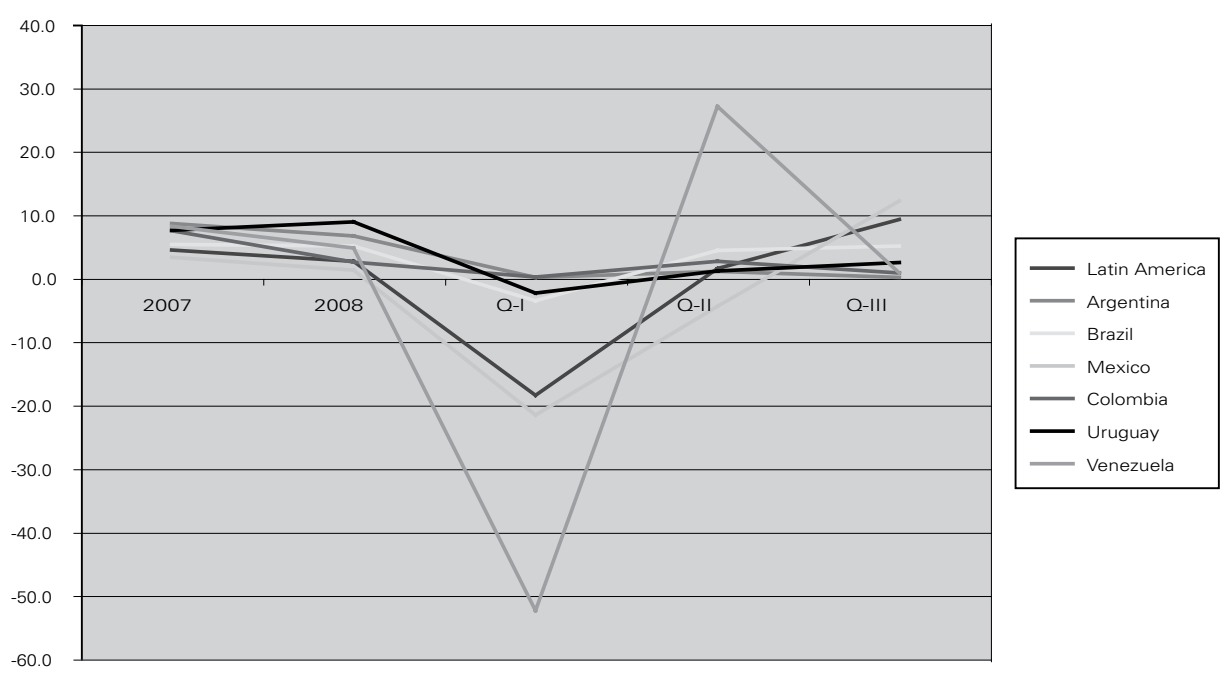

Source : CEPAL-CEPALSTAT, The Economist and http://www.cesla.com 
copper, $37.9 \%$. The countries in Latin America most affected by the drop in migrant remittances will be Mexico, Bolivia, Ecuador, and most of Central America and the Caribbean.

However, the factor that has probably affected the peripheral economies the most, above all the ones most linked up to international financial circuits, is the abrupt withdrawal of foreign capital flows. The Institute of International Finance predicts that private capital flows to emerging markets will decline to US\$ 165 billion in 2009, a sum considerably lower than 2008's US\$ 466 billion and 2007's record high of US\$929 billion. Resources draining out of the money and capital markets toward safer instruments like U.S. treasury bills not only affected financial variables, but also caused sharp currency devaluations in the last months of 2008 and the beginning of 2009. Later, with the return of portfolio capital flows, currencies have appreciated considerably, while stock markets have inflated (see Figure 4 and Table 5).

Figure 4: Exchange Rate Variation

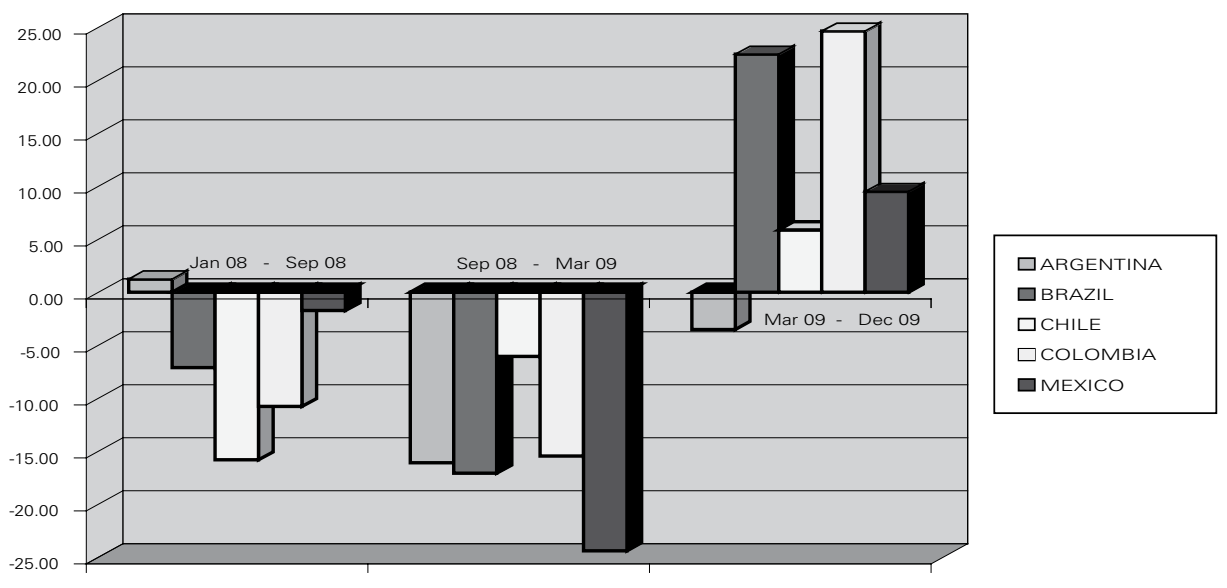

Source: http://www.banxico.org.mx

Table 5: Exchange Rate Variation

\begin{tabular}{|c|c|c|c|}
\hline COUNTRIES & Jan 08-Sep 08 & Sep 08 - Mar 09 & Mar 09 - Dec 09 \\
\hline ARGENTINA & 1.23 & -16.08 & -3.52 \\
BRAZIL & -7.11 & -17.08 & 22.44 \\
CHILE & -15.81 & -6.08 & 5.88 \\
COLOMBIA & -10.78 & -15.47 & 24.62 \\
MEXICO & -1.73 & -24.39 & 9.50 \\
\hline
\end{tabular}

Source: http://www.banxico.org.mx 
Because of the depth and generalized nature of the recession, the crisis's most ominous sign will be the swift rise in open unemployment, which will, in turn, aggravate it. In the countries of the periphery, where unemployment figures do not reflect reality, we will see a new expansion of the vast universe of the informal economy; but this time, there will be no escape valve in international migration. One UN specialist estimates that the crisis will spawn 50 million unemployed worldwide.

Contrary to the opinion of many analysts, the crisis in Latin America did not come from outside. Since the 1980s foreign debt crisis, countries of that region have passively inserted themselves in neoliberal globalization within the parameters established by the Washington Consensus. That was the main cause of the economic stagnation they experienced during the 1990s. Instead of contributing to the growth of domestic investment and employment, foreign capital inflows over-valued currencies; encouraged consumption and imports; stimulated governments and large corporations' foreign indebtedness; and created the conditions for the outbreak of severe financial crises, like the ones in Mexico in 1994-1995, in Brazil in 1999, and in Argentina in 2001 (Bresser-Pereira, 2007; Ffrench Davis, 2005; Guillén, 2010b).

Since the global crisis sets limits on globalization, the impossibility of maintaining export-driven accumulation sustained by restrictive monetary and fiscal policies becomes clear. World trade has collapsed to a degree not seen since the depression of the 1930s. Growth in the volume of world trade declined from $7.2 \%$ in 2007 to $3.3 \%$ in 2008 . By 2009, the IMF estimates an unprecedented contraction of $11 \%(2009 \mathrm{a}, \mathrm{p} .10)$. The global nature of the crisis makes it clear that getting out of it cannot depend on the external market. There is no way out this time for any country through exports. Although most governments are aware of the dangers of protectionism, it is clearly increasing and economies tend to close and look for ways out in the domestic sphere.

The best proof that the neoliberal model does not work in Latin America is the fact that the countries that managed to stave off stagnation in the previous expansionary period were the ones that shunned the Washington Consensus and tried alternative development strategies.

The same will apply to getting out of the crisis. Although the IMF states that "the worst is over for most of the countries" of Latin America and that recovery will come in 2010 (2009b, p. vii), the truth is that if it does happen, it will be very uneven.

Recession may be over but the crisis still has a long way to go. A lot will depend on the development model and the kind of economic policies that are adopted. Although there are important national differences, since the beginning of this century, Latin America has been split into two large blocs: one neoliberal space headed up by Mexico, Colombia, Peru, and a few Central American and Caribbean countries; and a growing "post-neoliberal progressive pole" that includes a broad gamut ranging from Chile's government or Lula's Brazil to the countries that aim to build "twenty-first century socialism" like Venezuela, Bolivia, or Ecuador. 
Brazil and Mexico are two contrasting development strategy experiences, which explains the differentiated impact of the crisis. In recent years, both have implemented pro-cyclical policies, but there are important differences in their development models and anti-crisis policies. Mexico, in the framework of NAFTA, bet on a "maquiladora" model, highly dependent on exports to the U.S. (see Figure 5), and undertook an aggressive program of privatizations, dismantling its public sector, which included handing over its banking system to foreign capital and practically eliminating the state development banks. Brazil, on the other hand, strengthened its vast domestic market, maintained an important national presence in its commercial banking system, and supports a strong state development banking system. In addition, it diversified even more its already diversified foreign trade and intensified its strategic and trade relations with China and other emerging powers at the same time that it fostered its integration with the countries of South America (Tavares, 2009).

Figure 5: Percentage of Exports to USA

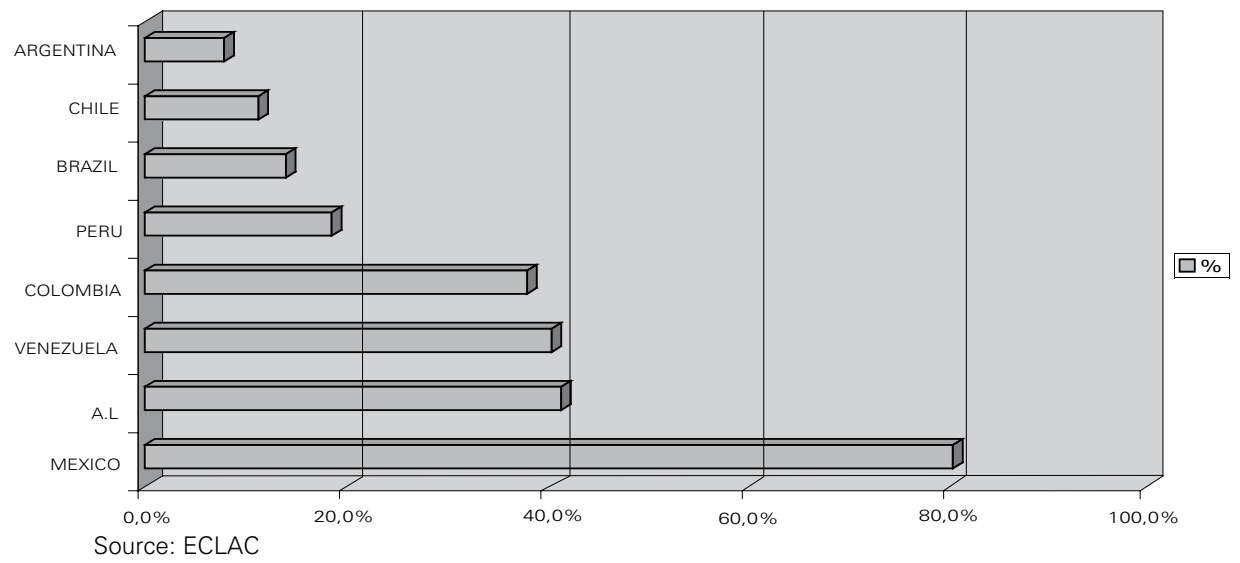

When faced with the crisis, the two countries' economic policies have also taken opposite paths. Mexico continues to be tied to the neoliberal myth of fiscal equilibrium and just passed a highly recessive, inflationary fiscal policy based on raising taxes on consumption and reducing public spending with the aim of staying in the good graces of financial capital and the rating agencies. Brazil, in contrast, has responded to the crisis with aggressive public works programs; it is avoiding taking on any new debt with the IMF and depends on its reserves to withstand any speculative runs on its currency. Mexico, on the other hand, is the only Latin American country that has accepted a line of credit for US\$ 47 billion from the IMF.

Given the differences in economic strategy, it is no accident that Brazil is emerging from the recession and closing out the year with a slight decrease in GDP $(0.7 \%)$, while Mexico will experience a 7 to $8 \%$ drop, the highest in the region. 


\section{CONCLUSIONS AND PERSPECTIVES}

The global crisis is going through a second stage characterized by a generalized recession whose synchronicity and depth is unparalleled since World War II and deepening deflationary tendencies in central countries.

Despite some symptoms of reactivation in the second quarter of 2009 associated with recovering inventories and the effects of salvage operations from governments, the crisis still has a long way to go. The process of destruction of capital has not concluded yet. Until now, the developed countries have dropped interest rates as much as they can and implemented aggressive fiscal programs to salvage their financial markets, break credit restrictions, and contain the recession without managing to substantially change the overall uncertainty the world economy is operating in. Quite to the contrary, the horizon is darkening with the advancing clouds of deflation interlocking with the recession.

This time, there will be no way out in external markets for any country. That fact will force them to restructure productive systems and search for a way out in domestic markets and in regional spaces for integration.

The situation in Latin America is complex, and it faces grave difficulties in the immediate future. The road taken by Mexico, Colombia and the countries closest to the Washington Consensus seems clear: to integrate more with the United States, subordinating themselves to the multilateral agencies, waiting until the deluge is over to re-launch the neoliberal model. For some, this may seem like an attractive scenario, but the social costs will be immense. Undoubtedly, structural heterogeneity, social inequalities, and poverty will deepen.

The way forward for the governments that define themselves as progressive - the majority in the region - is not easy either. In a world in convulsion, these governments will have to continue to remain stable and united; deepen their internal processes of economic and political transformation; continue the quest for and implementation of alternative strategies and policies; broaden out their relations with the emerging powers; and concretize and strengthen South-South integration.

\section{REFERENCES}

BORÓN, Atilio (2009) "De la guerra infinita a la crisis infinita." Paper presented at the XI Encuentro Internacional de Economistas sobre Globalización y Problemas del Desarrollo, Havana, Cuba, March 2-6.

BRESSER-PEREIRA, Luiz Carlos (2007) "El nuevo desarrollismo y la ortodoxia convencional”. Revista Economía-UNAM. Num. 10. Mexico City, UNAM, enero-abril: 7-29.

CHESNAIS, Francois (2009) "Situación mundial: como la crisis de 1929 o más...Un nuevo contexto mundial," available at http://www.cedla.org/obess/node/1197.

DE BERNIS, G. (1986) "Propuestas metodológicas para un análisis de la primera fase del 'trabajo de crisis' en la crisis del modo de regulación," in Arturo Guillén, et al., Naturaleza de la actual crisis. Mexico City, Editorial Nuestro Tiempo.

DE BERNIS, G. (1988) El capitalismo contemporáneo. Mexico City, Editorial Nuestro Tiempo. 
ECLAC (2008) Balance preliminar de las economías de América Latina y el Caribe, United Nations Economic Commission for Latin America and the Caribbean, Santiago de Chile. www.eclac.org. FOSTER, John Bellamy (2009) “A Failed System” Monthly Review. New York, March.

FFRENCH DAVIS, Ricardo (2005) Reformas para América Latina. Argentina, Siglo XXI editores-CEPAL.

GUILLÉN, Arturo (1991) "La fase deflacionaria de la crisis estructural.” Revista Problemas del Desarrollo no. 85, Mexico City, IIEC-UNAM. April-June.

GUILLÉN, Arturo (2007) Mito y realidad de la globalización neoliberal. Mexico City, Miguel Angel Porrúa Editores-UAMI.

GUILLÉN, Arturo (2009) “The party is over': la crisis global y la recesión generalizada.” Revista Economía UNAM 16, Mexico City, 2009, January-April.

GUILLÉN, Arturo (2010a) "La crisis global un año después del desplome financeiro: perspectivas de su salida in A. Guillén,” E. Correa and G. Vidal, et al. Capitalismo: ¿Recupeción? ¿Descomposición?; Mexico: Miguel Angel Porrúa editores-UAMI, (in press).

GUILLÉN, Arturo (2010b) “Obstáculo a la transformación de América Latina”, in J. Deniz, A. Guillén and G. Vidal et al. Desarrollo y transformación: opciones para América Latina, Madrid: F. C. E., 2010.

IMF (2009a) World Economic Outlook. Crisis and Recovery, International Monetary Fund, Washington, D.C.

IMF (2009b) Regional Economic Outlook. Western Hemisphere. Crisis averted-What's Next?, Washington.

PREBISCH, Raúl. ([1948] 1996). "El desarrollo económico de la América Latina y algunos de sus principales problemas.” El Trimestre Económico. vol. LXIII (1), no. 249. Mexico City, F.C.E.

SINGER, Hans. W. ([1949] 1996) "Comercio e inversión en países poco desarrollados. Distribución de las ganancias entre los países inversores y los deudores.” El Trimestre Económico. vol. LXIII (1), no. 249. Mexico City, F.C.E.

SOROS, George (2008) El nuevo paradigma de los mercados financieros. Mexico City, Taurus.

TAVARES, María de Conceição (2009). A crise financeira atual. Sao Paulo, mimeo. 2009.

THE ECONOMIST (2009) "House prices. caught in the downward current." London, 2009.March 19.

WOLF, Martin (2009) “The seeds of its own destruction.” Financial Times, London, March 9. 